\title{
ARTIKEL PEMODELAN READINESS DALAM PENGUKURAN \\ PENGGUNAAN SISTEM INFORMASI
}

\author{
Dede Fitri Sahrudin \\ Program Studi Sistem Informasi \\ STMIK Sumedang, Jl. Angkrek Situ No. 19, Sumedang 45323 Indonesia \\ Email : a3.1600006@mhs.stmik-sumedang.ac.id
}

Seiring dengan perkembangan zaman pada saat ini,pengembangan pengetahuan manusia dan teknologi kemajuan nya sangat cepat,dengan demikian kegiatan manusia sehari-hari terasa sangat amat terbantu karena teknologi pada saat ini memberikan kemudahan, efektifitas waktu,efektifitas biaya dan menghemat tenaga baik dalam dunia pekerjaan,sekolah ,industri dan lainya.Karena sebagian orang merasa teknologi sistem informasi mampu memecahkan masalah masalah ketidak efektifan yang mereka rasakan saat melakukan kegiatan-kegiatan yang menunjang kehidupan mereka.

Sistem informasi sendiri adalah ilmu yang mempelajari tentang teknologi informasi saat ini dan aktivitas manusia yang menggunakan teknologi tersebut untuk mendukung kehidupan dan juga manajemen. Menurut artian yang luas sistem informasi berarti interaksi antara manusia dengan teknologi yang melibatkan proses algoritma atau data. Bisa disimpulkan sistem informasi digunakan untuk mendukung penggunaan teknologi informasi dan komunikasi oleh individu atau organisasi.

Tujuan utama dengan adanya sistem informasi adalah untuk menghasilkan informasi. Sistem informasi data yang diciptakan menjadi suatu bentuk yang berguna bagi manusia. Maka dari itu, untuk bisa dimanfaatkan oleh masyarakat sistem informasi harus didukung oleh 3 pilar utama, yakni tepat penggunanya atau relevan, tepat waktu dan akurat atau tepat nilainya.

Model Readiness merupakan model yang mengukur kesiapan sumberdaya dalam menggunakan sistem informasi.Misalnya kesiapan sebuah toko dalam menggunakan sistem informasi penjualan yang mempermudah mencari sebuah iformasi penjualan di toko tersebut untuk mengambil sebuah keputusan.Dengan demikian Readiness atau kesiapan merupakan suatu analisis pengukuran kesiapan sumber daya dalam menggunakan sistem informasi mulai dari perangkat pendukung berjalannya sistem dan beberapa user agar tujuan pembuatan sistem informasi tersebut mencapai keefektifitasan.

Pemodelan yang akan digunakan yaitu Technologi Readiness Index,Berikut ini beberapa artikel yang menggunakan pemodelan tersebut ;

Yang pertama yaitu “ANALISIS KESIAPAN PENGGUNA SISTEM INFORMASI AKADEMIK" Suluh Argo Pambudi 1) 1) Teknik Informatika STMIK AMIKOM Yogyakarta 1) Jl Ring road Utara, Condongcatur, Sleman, Yogyakarta 55281 Email : suargo@gmail.com1) Abstrak Kesuksesan implementasi maupun adopsi teknologi baru terutama Teknologi Infomasi dan Komunikasi (TIK) pada sebuah institusi sangat ditentukan oleh faktor kesiapan dan kemampuan pengguna, dalam hal ini adalah pengguna SIA tersebut. Penelitian ini bertujuan untuk melakukan analisis kesiapan 
kompetensi teknologi pengguna pada proses implementasi SIA Politeknik Negeri Madiun (PNM) dengan pengukuran kesiapan dianalisis menggunakan teknik Structural Equation Modelling (SEM) dengan pendekatan Partial Least Square (PLS) dan menggunakan metode Technology Readiness Index (TRI). Berdasarkan hasil penelitian dapat disimpulan kesiapan pengguna SIA PNM, secara umum berada pada tingkat yang cukup dengan index faktor ketidaknyamanan menempati urutan teratas dan index inovasi memiliki score rendah. Kata kunci: Kesiapan pengguna, Technology Readiness Index. Berdasarkan latar belakang masalah yang telah diuraikan di atas, maka permasalahan yang akan dibahas dalam penelitian ini dirumuskan :

1. Bagaimana mengukur kesiapan pengguna terhadap implementasi Sistem Informasi Akademik Politeknik Negeri Madiun.

2. Berapa besar pengaruh index kesiapan pengguna terhadap implementasi Sistem Informasi Akademik Politeknik Negeri Madiun.

3. Kebijakan apa yang harus diambil oleh pihak manajemen dengan mengetahui besar pengaruh kesiapan pengguna terhadap implementasi Sistem Informasi Akademik Politeknik Negeri Madiun. Metode Penelitian Penelitian ini mengadopsi metode Technology Readiness Index (TRI) dan jenis penelitian yang digunakan adalah confirmatory atau explanatory research. Technology readiness (TR) diidentifikasi sebagai “people's propensity to embrace and use new technology for accomplishing goal in home life and at work" [9]. Berdasar tingkat TR pengguna TIK dapat dikategorikan menjadi 5 [5]. Pengguna TIK dengan tingkat optimisme dan inovasi yang tinggi masuk dalam kategori Explorer, merupakan individu-individu yang memiliki motivasi dan rasa percaya diri yang paling tinggi dibanding kategori yang lain terhadap kemampuannya dalam menggunakan teknologi, masih berusia muda,umumnya laki-laki, memiliki penghasilan dan pendidikan yang lebih tinggi. Kategori yang kedua adalah Pioneer, merupakan individu- individu yang memiliki tingkat optimisme dan inovasi di atas ratarata, tetapi memiliki sedikit resistensi terhadap teknologi. Pioneer memiliki tingkat penghasilan dan pendidikan rata-rata, berusia muda dan biasanya perempuan.Pengguna TIK dengan tingkat ketidaknyamanan dan ketidakamanan yang tinggi masuk dalam kategori Paranoid atau Laggard (lamban/gagap teknologi).Individu yang masuk dalam kategori Paranoid, percaya pada teknologi dan optimis tetapi tidak memiliki kecenderungan untuk berinovasi, berusia di atas rata-rata dengan penghasilan dan pendidikan lebih rendah, dan umumnya perempuan. Individu yang masuk dalam kategori Laggard (lamban/gagap teknologi) merupakan individu-individu yang sudah berusia tua, biasanya perempuan dengan tingkat penghasilan dan pendidikan yang rendah. Kategori yang terakhir adalah Skeptic merupakan kategori yang berada di tengah di antara 5 kategori berdasar tingkat TR yang ada Individu yang masuk dalam kategori ini tidak melawan teknologi,mereka hanya kurang antusias, dan cenderung tidak percaya bahwa teknologi menawarkan lebih banyak kontrol atas hidup mereka. TRI merupakan indeks untuk mengukur kesiapan pengguna terhadap teknologi baru dengan empat variabel yaitu: (1) optimism (optimisme), sikap pandang positif terhadap teknologi dan percaya bahwa teknologi akan meningkatkan kontrol, fleksibilitas, dan,efisiensi dalam kehidupan; (2) innovativeness 
(inovasi), sikap tendensi untuk yang pertama menggunakan produk maupun layanan teknologi baru; (3) discomfort (ketidaknyamanan), memiliki sikap sulit mengontrol dan cenderung kewalahan atau tidak percaya diri ketika berhadapan dengan teknologi baru; dan (4) insecurity (ketidakamanan), memiliki kecurigaan terhadap keamaanan teknologi dan alasan keamanan data pribadi. Tingkat kompetensi pengguna teknologi informasi menjadi faktor utama penentu kesuksesan adopsi teknologi informasi. Lingkungan dengan tingkat penguasaan teknologi informasi yang tinggi biasanya lebih adaptif terhadap kehadiran sistem informasi baru sehingga implementasi sistem informasi baru cenderung lebih mudah dibandingkan pada lingkungan dengan kondisi sebaliknya [7]. Pembahasan Responden dari penelitian ini adalah pengguna Sistem Informasi Akademik Politeknik Negeri Madiun (PNM), tidak hanya jajaran Direksi tetapi juga pengguna yang tersebar di Direksi, Bagian Umum, Bagian Keuangan, Kepegawaian, Pengadaan Barang dan Jasa, Sarana Prasarana, Administrasi Akademik,Dosen,Mahasiswa. Distribusi kuesioner bisa dilihat pada table di bawah ini :

Tabel 1. Distribusi Kuesioner

\begin{tabular}{|l|c|c|c|}
\hline \multicolumn{1}{|c|}{ Unit Kerja } & $\begin{array}{c}\text { Distribusi } \\
\text { (n) }\end{array}$ & $\begin{array}{c}\text { Kembali } \\
\text { (n) }\end{array}$ & $\begin{array}{c}\text { Prosentase } \\
\text { (\%) }\end{array}$ \\
\hline Direksi & 8 & 8 & 100 \\
\hline $\begin{array}{l}\text { Bagian Umum dan } \\
\text { Akademik }\end{array}$ & 4 & 4 & 100 \\
\hline Sub Bagian Umum & 4 & 3 & 75 \\
\hline Sub BAAK & 3 & 3 & 100 \\
\hline $\begin{array}{l}\text { Sub Bagian } \\
\text { Kepegawaian }\end{array}$ & 4 & 3 & 75 \\
\hline Sub Bagian Keuangan & 5 & 3 & 60 \\
\hline $\begin{array}{l}\text { Bagian Pengadaan } \\
\text { Barang dan Jasa }\end{array}$ & 8 & 2 & 25 \\
\hline Jurusan Teknik & 4 & 4 & 100 \\
\hline $\begin{array}{l}\text { Jurusan Admnistrasi } \\
\text { Bisnis }\end{array}$ & 32 & 26 & 81,25 \\
\hline $\begin{array}{l}\text { Jurusan Komputerisasi } \\
\text { Akuntansi }\end{array}$ & 34 & 28 & 82,35 \\
\hline $\begin{array}{l}\text { Prodi Teknik Komputer } \\
\text { Kontrol }\end{array}$ & 18 & 12 & 66,67 \\
\hline ProdiTeknik Listrik & 12 & 7 & 58,33 \\
\hline Prodi Mesin Otomotif & 12 & 10 & 83,33 \\
\hline Prodi Bahasa Inggris & 6 & 4 & 66,67 \\
\hline TOTAL & $\mathbf{1 5 4}$ & $\mathbf{1 1 3}$ & $\mathbf{6 3 , 5}$ \\
\hline
\end{tabular}

Sebanyak 113 kuesioner dari 154 kuesioner atau sebesar 
63,50\% diterima kembali oleh peneliti.

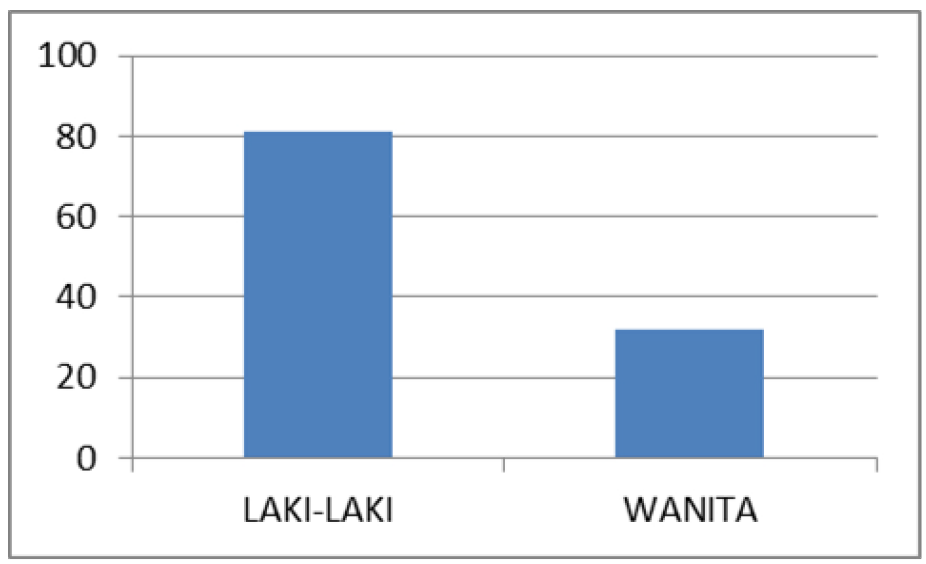

Gambar 1. Jenis Kelamin Responden

Pada Gambar 1 terlihat bahwa responden penelitian sebanyak 81 orang $(71,69 \%)$ berjenis kelamin lakilaki dan 32 orang $(28,77 \%)$ berjenis kelamin perempuan.

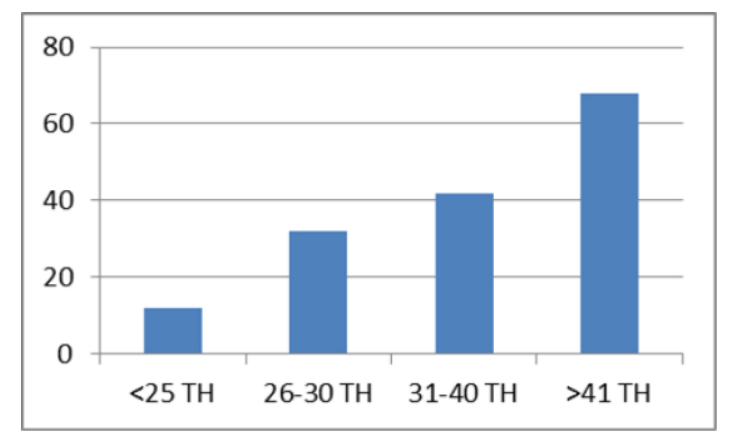

Gambar 2. Usia Responden

Usia responden paling banyak berusia diatas 40 tahun, diikuti usia 30 - 40 tahun, selanjutnya usia lebih dari 25 - 30 tahun dan hanya sedikit yang berusia di bawah 25 tahun. MerujukAnggraeni [10], usia antara 31 - 40 merupakan usia yang ideal bagi seseorang untuk mengaplikasikan idealisme dan menyenangi pekerjaan yang bersifat menantang. Usia 31 - 40 tahun di Politeknik Negeri Madiun saat ini berjumlah 22 orang, dan tenaga kerja usia diatas 41 tahun masih mendominasi dengan jumlah 48 orang. Jumlah tenaga kerja pada usia 26 - 30 tahun sebanyak 32 orang dan pada usia di bawah 25 tahun sebanyak 11 orang.

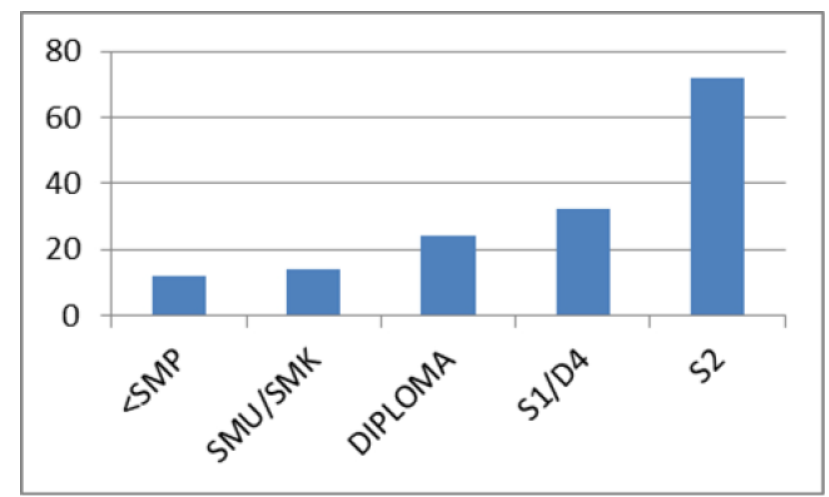

Gambar 3. Tingkat Pendidikan Responden 
Tingkat pendidikan responden paling banyak adalah S2, yaitu sebanyak 52 orang (46,75\%), terdiri dari dosen dan struktural unit kerja, diikuti S1/D4 sebanyak 21 orang (20,78\%), terdiri atas pranata laboratorium, staf laboratorium, pimpinan sub bagian, dan lain-lain. Diploma III sebanyak 18 orang $(15,59 \%)$, berada di staff administrasi. Pendidikan setingkat SMU/SMK sebanyak 10 orang (9.09\%), sebagai penjaga dan sopir, dan Pendidikan setingkat SMP dan dibawahnya sebanyak 12 orang $(7,79 \%)$ sebagai cleaning service dan pantry.

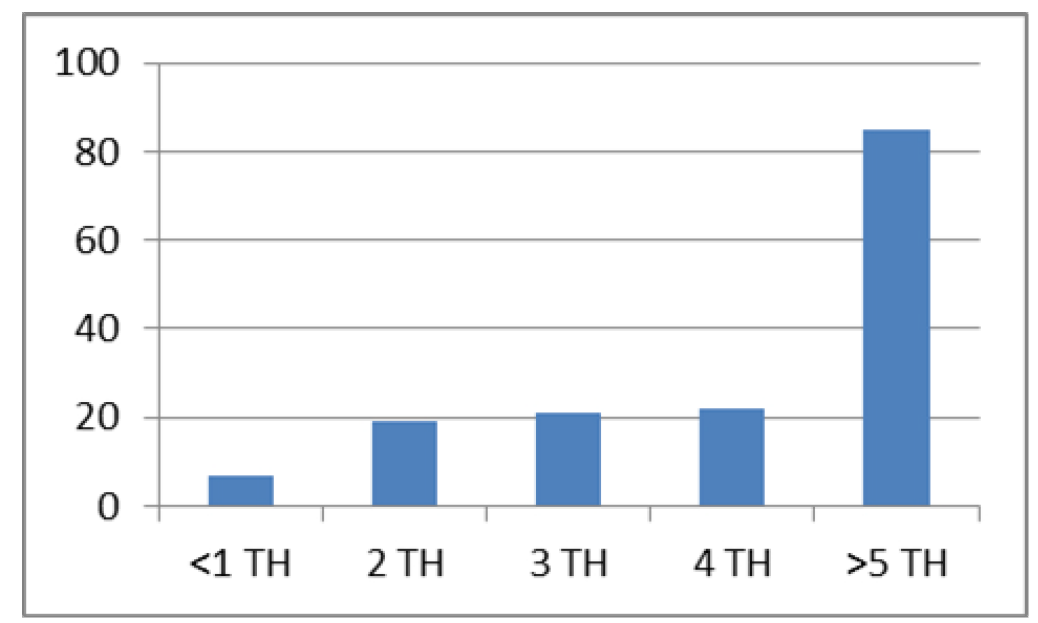

Gambar 4. Pengalaman Menggunakan TIK

Pengalaman responden dalam menggunakan TIK didominasi oleh responden dengan pengalaman di atas 5 tahun, yaitu sebanyak 70 orang $(55,19 \%)$, kemudian responden dengan pengalaman 4 tahun sebanyak 14 orang $(14,28 \%)$, responden dengan penglaman 3 tahun sebanyak 13 orang (13,64\%), responden dengan pengalaman 2 tahun sebanyak 9 orang (12,33\%), dan responden dengan pengalaman kurang dari 1 tahun sebanyak 7 orang $(4,54 \%)$.

\subsection{Varibel Indikator}


Variabel indikator yang digunakan pada penelitian ini mengacu pada variable Technology Readiness Index,bisa dilihat pada tabel 2 dibawah ini :

Tabel 2. Variabel Indikator

\begin{tabular}{|c|c|c|}
\hline $\begin{array}{l}\text { Variabel } \\
\text { Laten }\end{array}$ & Indikator Variabel & Kode \\
\hline \multirow{2}{*}{$\begin{array}{l}\text { Optimisme } \\
\text { (OPT) }\end{array}$} & SIA memotivasi pekerjaan & OPT1 \\
\hline & \begin{tabular}{|l|} 
Bisa mengembangkan sistem \\
untuk kebutuhan pekerjaan
\end{tabular} & OPT2 \\
\hline \multirow{3}{*}{$\begin{array}{l}\text { Inovasi } \\
(\mathrm{INN})\end{array}$} & \begin{tabular}{|lll} 
Dapat menguasai & SIA dengan \\
mudah
\end{tabular} & INN1 \\
\hline & $\begin{array}{l}\text { Teman-teman meminta bantuan } \\
\text { berhubungan dengan SIA }\end{array}$ & INN2 \\
\hline & $\begin{array}{l}\text { Dapat menyeleseikan masalah } \\
\text { yang berkaitan denan SIA }\end{array}$ & INN3 \\
\hline \multirow{2}{*}{$\begin{array}{l}\text { Ketidaknya } \\
\text { manan } \\
\text { (DIS) }\end{array}$} & $\begin{array}{l}\text { Saat kesulitan memahami SIA dan } \\
\text { bertanya ke orang lain, merasa } \\
\text { dimanfaatkan oleh orang yang } \\
\text { lebih tau }\end{array}$ & DIS1 \\
\hline & $\begin{array}{l}\text { Merasa malu saat bermasalah } \\
\text { dengan SIA }\end{array}$ & DIS2 \\
\hline \multirow{2}{*}{$\begin{array}{l}\text { Ketidak } \\
\text { amanan } \\
\text { (INS) }\end{array}$} & $\begin{array}{l}\text { Tidak yakin data yang dikerjakan } \\
\text { dan dikirim melalui SIA sampai } \\
\text { tujuan }\end{array}$ & INS1 \\
\hline & $\begin{array}{l}\text { Tidak memperhatikan keamanan } \\
\text { dalam bekerja dengan SIA }\end{array}$ & INS2 \\
\hline
\end{tabular}

Analisa data menggunakan teknik analisis SEM dengan pendekatan Partial Least Square (PLS). Langkah pertama yang dilakukan adalah memasukkan data mentah/primer ke dalam format Excel. Analisis dengan smartPLS dilakukan dengan cara menilai outer model (measurement model), dan menilai inner model (structural model). Evaluasi outer model dilakukan dalam 3 tahapan yaitu convergent validity, discriminant validity dan composite reliability. Masingmasing tahapan tersebut dapat dijelaskan dalam subbab berikut.

Convergent validity Convergent validity (besarnya nilai loading factor untuk masing-masing konstruk) dari outer model dengan indikator refleksif dapat dilihat dari korelasi antara score item/indikator dengan score konstruknya. Indikator individu dianggap reliabel jika memiliki nilai korelasi lebih besar dari 0,70. Namun demikian pada riset tahap pengembangan skala, nilai loading 0,50 sampai 0,60 masih dapat diterima [1]. Penelitian ini akan menggunakan nilai loading 0,50 sebagai nilai cut off, jika terdapat nilai loading lebih kecil dari 0,50 maka indikator yang bersangkutan akan dibuang karena mengindikasikan bahwa indikator tidak cukup baik untuk mengukur variabel secara tepat. 


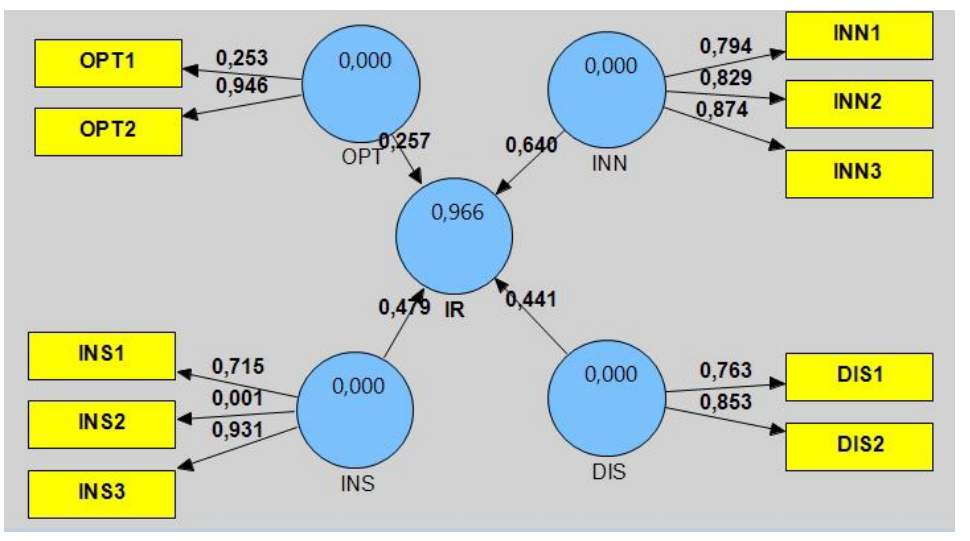

Gambar 5. Convergent Validity

Hasil convergent validity masing-masing outer model sebagai berikut:

a. Pada konstruk Optimisme, indikator OPT1 memilikimnilai loading sebesar 0,253. Indikator OPT1 selanjutnya dibuang karena nilai ini tidak memenuhi convergent validity0,50. Sedangkan indikator OPT2 memiliki nilai loading sebesar 1, lebih besar dari convergent validity.

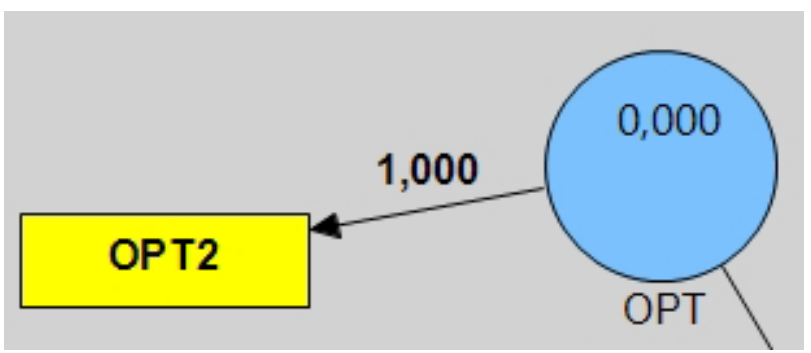

Gambar 6. Covergent validity untuk konstruk Optimisme

b. Pada konstruk Inovasi nilai loading indikator INN1 sebesar 0,794, INN2 sebesar 0,829, dan INN3 sebesar 0,874 terbukti signifikan memenuhi convergent validity.

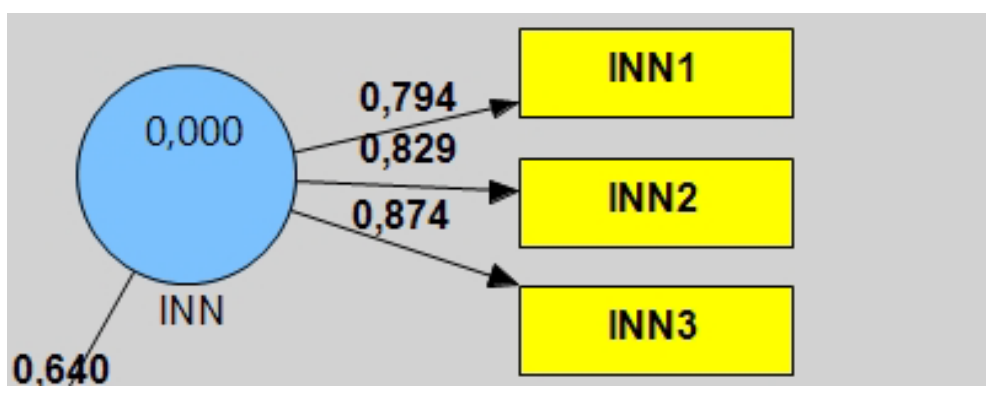

Gambar 7. Convergent validity untuk konstruk inovasi

c. Pada konstruk Ketidaknyamanan, dua indikator yang digunakan terbukti signifikan memenuhi convergent validity. Nilai loading masing-masing indikator adalah DIS1 sebesar 0,763 dan DIS2 sebesar 0,853 .

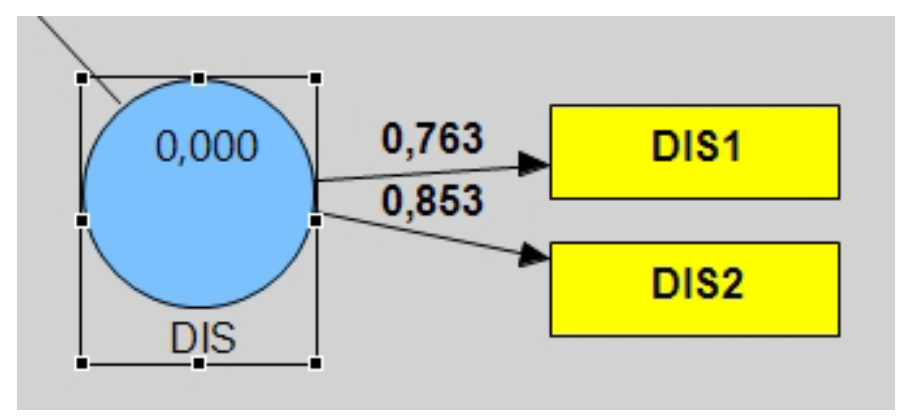

Gambar 8. Convergent validityuntuk konstruk Ketidaknyamanan 
d. Konstruk Ketidakamanan memiliki 1 indikator dengan nilai loading dibawah 0,50, yaitu INS2 dengan nilai 0.321, sehingga harus dibuang. Sedangkan INS1 memiliki nilai 0,715 dan INS 3 memiliki nilai 0,931 memenuhi convergent validity.

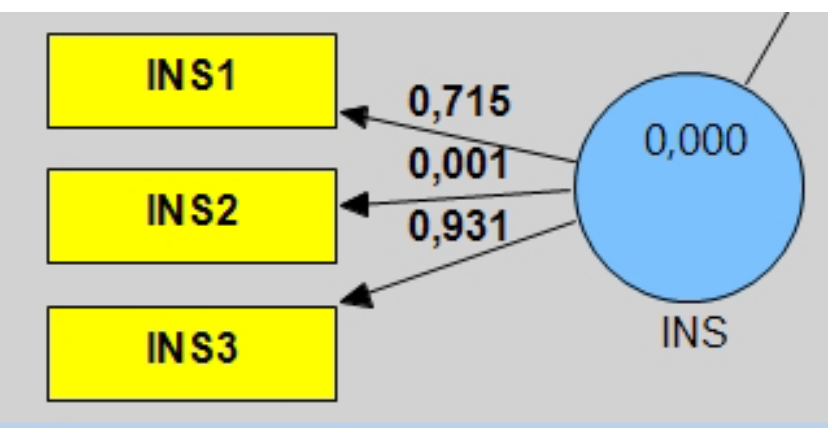

Gambar 9. Convergent validity untuk konstruk ketidakamanan

Dengan pembuangan indikator yang tidak signifikan untuk digunakan sebagai pengukur terhadap konstruknya, secara keseluruhan outer model menjadi seperti Gambar 10 di bawah ini.

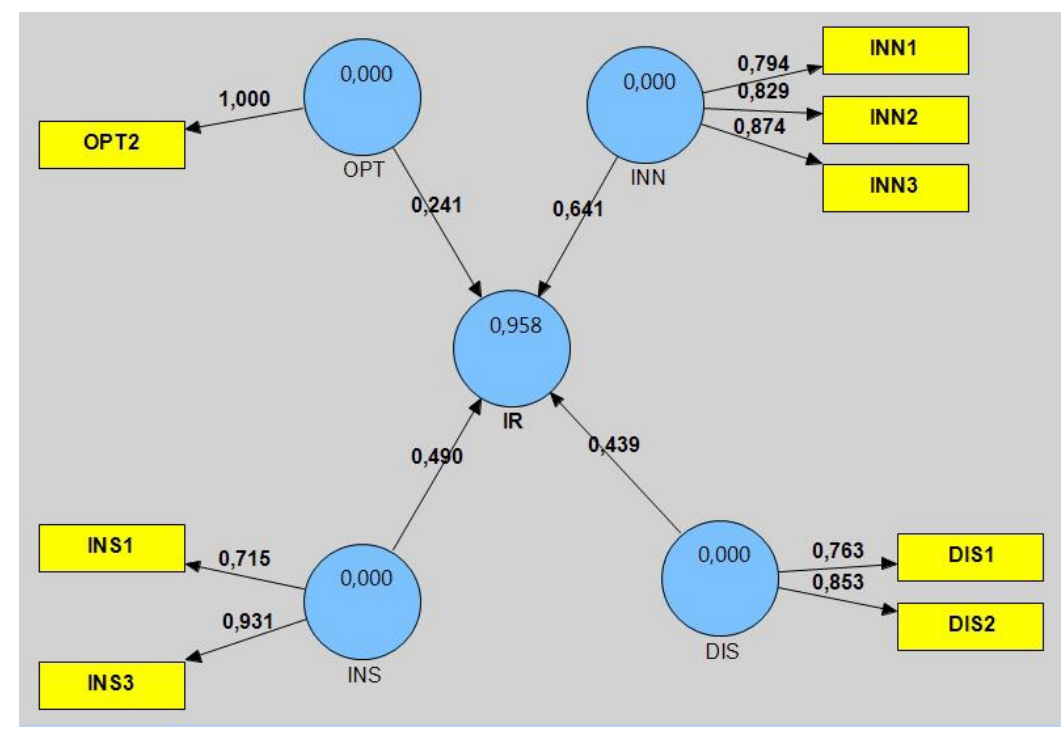

Gambar 10. Convergent validity dari Outer Model

\section{Discriminant validity}

Untuk mengukur tingkat discriminant validity adalah membandingkan nilai akar average variance extracted (AVE) pada setiap konstruk dengan korelasi antara konstruk dengan konstruk lainnya dalam model. Formula untuk menghitung AVE adalah :

$\Sigma[\lambda \mathrm{i} 2]$

$\mathrm{AVE}=-\Sigma[\lambda \mathrm{i} 2]+\Sigma[\operatorname{Var}(\varepsilon \mathrm{i})]$

Dimana $\lambda \mathrm{i}$ adalah component loading indicator, dan $\operatorname{Var}(\square \mathrm{i})=1-\lambda \mathrm{i} 2$.

Fornell dan Larker's (1981) dalam I. Ghozali (2008) [3] menjelaskan bahwa sebuah konstruk laten memiliki validitas diskriminan yang memuaskan apabila memiliki nilai AVE yang lebih besar daripada korelasi kuadrat konstrak laten tersebut dengan konstrak laten lainnya. Besarnya nilai AVE minimal yang direkomendasikan adalah 0,5. Jika nilai AVE didapatkan lebih besar dari 0,5 maka indikatorindikator di dalam model yang dikembangkan terbukti benar-benar mengukur konstrak laten yang ditargetkan dan tidak mengukur konstrak laten yang lain. Nilai korelasi antar konstruk dan akar AVE 
dalam penelitian ini seperti pada Tabel 3 yang merupakan hasil PLS pengolahan data primer di bawah ini.

Tabel 3. Korelasi antar konstruk dan akar AVE

\begin{tabular}{|c|c|c|c|c|c|}
\hline & DIS & INN & INS & IR & OPT \\
\hline DIS & $1^{*}$ & 0 & 0 & 0 & 0 \\
\hline INN & 0,1788 & $1^{*}$ & 0 & 0 & 0 \\
\hline INS & 0,1948 & $-0,2565$ & $1^{*}$ & 0 & 0 \\
\hline IR & 0,6527 & 0,67 & 0,3416 & $1^{*}$ & 0 \\
\hline OPT & 0,0144 & 0,315 & $-0,2867$ & 0,309 & $1^{*}$ \\
\hline
\end{tabular}

Berdasarkan di atas menunjukkan bahwa nilai akar AVE (bertanda “*”) lebih besar dibandingkan dengan korelasi antar konstruk yaitu nilai yang berada dalam satu baris maupun kolom yang sama dengan nilai akar AVE masing-masing konstruk. Hal ini berarti masing masing konstruk dalam model penelitian memiliki tingkat discriminant validity yang tinggi, sehingga dapat disimpulkan bahwa semua konstruk dalam penelitian sudah memenuhi discriminant validity.

Composite reliability Composite reliability dikatakan reliable jika nilainya lebih besar dari 0,60 [2].

Tabel 4. Quality Criteria

\begin{tabular}{|c|c|c|c|c|}
\hline & AVE & $\begin{array}{c}\text { Composite } \\
\text { Reliability }\end{array}$ & R Square & $\begin{array}{c}\text { Cronbachs } \\
\text { Alpha }\end{array}$ \\
\hline DIS & 0,6551 & 0,7911 & 0 & 0,4778 \\
\hline INN & 0,6938 & 0,8716 & 0 & 0,7783 \\
\hline INS & 0,689 & 0,8133 & 0 & 0,5818 \\
\hline IR & 1 & 1 & 0,958 & 1 \\
\hline OPT & 1 & 1 & 0 & 1 \\
\hline
\end{tabular}

Tabel di atas menunjukkan hasil composite reliability yang memuaskan, karena keseluruhan nilai composite reliability yang mengukur konstruk sebagian lebih besar dari 0,60

Evaluasi inner model (structural model) Pengujian inner model dilakukan untuk melihat hubungan antar variabel/konstruk, nilai signifikansi dan R-square dari model penelitian. Inner model dievaluasi dengan menggunakan uji t, signifikansi dari koefisien parameter jalur struktural dan R-square untuk variabel endogen.

Tabel 5. R-square
\begin{tabular}{|c|c|}
\hline & R Square \\
\hline DIS & 0 \\
\hline INN & 0 \\
\hline INS & 0 \\
\hline IR & 0,958 \\
\hline OPT & 0 \\
\hline
\end{tabular}

Untuk mendukung pengujian dengan R-square tersebut, pengujian dengan uji t dilakukan.

\begin{tabular}{|c|c|c|c|}
\multicolumn{4}{c}{ Tabel 6. Hasil uji t } \\
\hline & $\begin{array}{c}\text { T } \\
\text { statatistics }\end{array}$ & $\begin{array}{c}\text { T Tabel } \\
(\mathbf{p}=\mathbf{0 , 0 0 1 )}\end{array}$ & Kesimpulan \\
\hline DIS->IR & 12,455 & 3,551 & Berpengaruh \\
\hline INN->IR & 11,164 & 3,551 & Berpengaruh \\
\hline INS->IR & 8,167 & 3,551 & Berpengaruh \\
\hline OPT-> & 7,231 & 3,551 & Berpengaruh \\
\hline
\end{tabular}


Dari table R-square dan hasil uji t mengindikasikan bahwa variabel eksogen dalam model penelitian (variabel optimisme, variabel inovasi, variabel ketidaknyamanan dan variabel ketidakamanan) berpengaruh sempurna atau dapat menjelaskan $100 \%$ terhadap variabel endogen, yaitu variabel technology readiness.

Kemudian yang kedua, "KESIAPAN PENGGUNA INTRANET BERBASIS ANDROID DI KEMENTERIAN PERINDUSTRIAN"Eko Sulistiyo Wibowo1), Adhi Susanto2), Wing Wahyu Winarno3)1), 2), 3) Teknik Elektro dan Teknologi Informasi UGM Yogyakarta

Jl Grafika Nomor 2, Kampus UGM, Yogyakarta 55281 Email: eko.sulistiyo.wibowo@gmail.com1) ,adhisusanto@jmn.net.id2),maswing@gmail.com3)

Abstrak Intranet merupakan sistem informasi internal berbasis web di Kementerian Perindustrian yang mendukung kemudahan dan kecepatan kinerja pegawai dan organisasi dalam rangka peningkatan efektivitas dan efisiensi layanan ke publik. Kebijakan tunjangan kinerja pegawai di Kemenperin (2012) menuntut setiap pegawai untuk rutin mengakses Intranet guna mendokumentasikan kinerjanya. Aplikasi mobile berbasis Android perlu

dipertimbangkan sebagai teknologi baru untuk Intranet Kemenperin. Penelitian ini melakukan pengukuran kesiapan pengguna aplikasi mobile berbasis android untuk Intranet Kemenperin dengan menggunakan model penilaian kesiapan CID Harvard, suatu model penilaian kesiapan yang cocok untuk negara berkembang seperti Indonesia. Dari lima kategori kesiapan, penelitian ini fokus pada tiga kategori, yaitu network access, networked society, dan networked economy. Penelitian menggunakan data dari 385 responden yang diperoleh dari penyebaran kuesioner online dengan metode simplerandom sampling. Hasil penelitian menunjukkan bahwa kesiapan pengguna Intranet berada pada tingkat 4 (dari 4 tingkat kesiapan) yang berarti sudah sangat siap dengan aplikasi mobile berbasis android untuk Intranet Kemenperin.Kata kunci: E-Government, Kesiapan, CID Harvard,Android.

Masalah dalam penelitian ini adalah bagaimanakah tingkat kesiapan pegawai Kemenperin terhadap aplikasi mobile berbasis Android sebagai teknologi baru untuk Intranet Kemenperin. Pemanfaatan TIK dalam proses pemerintahan akan meningkatkan efisiensi, efektivitas, transparansi, dan akuntabilitas penyelenggaraan pemerintahan. Tahun 2003 Presiden RI mengeluarkan instruksi tentang

kebijakan dan strategi nasional pengembangan e-government guna penyelenggaraan pemerintahan yang baik dan peningkatan layanan publik yang efektif dan efisien . Kementerian Perindustrian menyambut Instruksi Presiden dengan membuat sistem informasi eksternal (http://www.kemenperin.go.id) dan sistem informasi internal (http://intranet.kemenperin.go.id). Intranet Kemenperin yang berbasis web baru berisi basis data pegawai dan aplikasi absensi.

Model penilaian kesiapan yang digunakan adalah CID 
Harvard yang memiliki 5 kategori kesiapan. Penelitian ini hanya fokus pada 3 kategori saja, yaitu network access, networked society, dan networked economy.Penelitian ini menggunakan metode kuantitatif melalui kuesioner online yang diinformasikan kepada pengguna Intranet Kemenperin. Kuesioner berisi 30 pertanyaan sesuai dengan kerangka CID Harvard, dan dijawab dengan skala guttman (ya dan tidak) oleh responden.Setelah dilakukan uji validitas dan uji reliabilitas instrumen, data dianalisis dan disajikan dengan bantuan perangkat lunak pengolah angka Microsoft Excel.

Model penilaian kesiapan CID Harvard yang digunakan dalam penelitian ini fokus pada tiga kategori, yaitu network access, networked society, dan networkedeconomy. Masing-masing kategori memiliki beberapa indikator yang dijabarkan lagi menjadi satu atau beberapa pertanyaan yang mendukung tujuan dari penelitian ini, yaitu untuk mengetahui kesiapan pengguna Intranet Kemenperin terhadap teknologi baru berupa aplikasi mobile berbasis Android.

Tabel . Hasil Kuesioner Kesiapan per Indikator

\begin{tabular}{|c|c|c|c|c|c|}
\hline Indikator & Item & \begin{tabular}{|c|} 
Jumlah \\
YA
\end{tabular} & \begin{tabular}{|c|} 
Persentase \\
YA
\end{tabular} & \begin{tabular}{|l|} 
Persentase \\
indilkator
\end{tabular} & Stage \\
\hline \multicolumn{6}{|c|}{ Network Access } \\
\hline \multirow{3}{*}{$\begin{array}{l}\text { Information } \\
\text { Infrastructure }\end{array}$} & 1 & 384 & $99.74 \%$ & \multirow{3}{*}{$93.16 \%$} & \multirow{3}{*}{4} \\
\hline & 2 & 365 & $94.81 \%$ & & \\
\hline & 3 & 327 & $84.94 \%$ & & \\
\hline \multirow{3}{*}{$\begin{array}{l}\text { Intemet } \\
\text { Availability }\end{array}$} & 4 & 307 & $79.74 \%$ & \multirow{3}{*}{$81.30 \%$} & \multirow{3}{*}{4} \\
\hline & 5 & 380 & $96.70 \%$ & & \\
\hline & 6 & 252 & $65.45 \%$ & & \\
\hline \begin{tabular}{|l|} 
Intemet \\
Affordability
\end{tabular} & 7 & 371 & $96.36 \%$ & $96.36 \%$ & 4 \\
\hline \multirow{2}{*}{$\begin{array}{l}\text { Network } \\
\text { Speed and } \\
\text { Quality }\end{array}$} & 8 & 268 & $69.61 \%$ & \multirow{2}{*}{$64.55 \%$} & \multirow{2}{*}{3} \\
\hline & 9 & 229 & $59.48 \%$ & & \\
\hline \multirow{3}{*}{$\begin{array}{l}\text { Hardware and } \\
\text { Softwere }\end{array}$} & 10 & 327 & $84.94 \%$ & \multirow{3}{*}{$74.46 \%$} & \multirow{3}{*}{3} \\
\hline & 11 & 270 & $70.13 \%$ & & \\
\hline & 12 & 263 & $68.31 \%$ & & \\
\hline \multirow{2}{*}{$\begin{array}{l}\text { Service and } \\
\text { supoort }\end{array}$} & 13 & 354 & $91.95 \%$ & \multirow[b]{2}{*}{$90.26 \%$} & \multirow{2}{*}{4} \\
\hline & 14 & 341 & $88.57 \%$ & & \\
\hline \multicolumn{6}{|c|}{\begin{tabular}{|l} 
Networked Society \\
\end{tabular}} \\
\hline \multirow{3}{*}{$\begin{array}{l}\text { People and } \\
\text { Organization } \\
\text { s Online }\end{array}$} & 16 & 378 & $98.18 \%$ & \multirow{3}{*}{$96.24 \%$} & \multirow{3}{*}{4} \\
\hline & 17 & 338 & $87.79 \%$ & & \\
\hline & 18 & 384 & $99.74 \%$ & & \\
\hline \begin{tabular}{|l|} 
Locally \\
Relevant \\
Cortert
\end{tabular} & 19 & 333 & $86.49 \%$ & $86.49 \%$ & 4 \\
\hline \multirow{3}{*}{\begin{tabular}{|l|} 
ICTs in \\
Everyday \\
Life
\end{tabular}} & 21 & 380 & $98.70 \%$ & \multirow{3}{*}{$89.78 \%$} & \multirow{3}{*}{4} \\
\hline & 22 & 352 & $91.43 \%$ & & \\
\hline & 23 & 305 & $79.22 \%$ & & \\
\hline \multirow{2}{*}{$\begin{array}{l}\text { ICTs in the } \\
\text { Workplace }\end{array}$} & 24 & 336 & $87.27 \%$ & \multirow{2}{*}{$92.34 \%$} & \multirow{2}{*}{4} \\
\hline & 25 & 375 & $97.40 \%$ & & \\
\hline \multicolumn{6}{|c|}{\begin{tabular}{|l|} 
Networked Economy \\
\end{tabular}} \\
\hline $\begin{array}{l}B 2 C \\
\text { Bectronic } \\
\text { Conmerce }\end{array}$ & 27 & 266 & $\varpi .09 \%$ & $6.09 \%$ & 3 \\
\hline \begin{tabular}{|l|}
$B 2 B$ \\
Bectronic \\
Commerce
\end{tabular} & 28 & 375 & $97.40 \%$ & $97.40 \%$ & 4 \\
\hline \multirow{2}{*}{$\begin{array}{l}\text { E- } \\
\text { Govemment }\end{array}$} & 29 & 364 & $94.55 \%$ & \multirow{2}{*}{$91.17 \%$} & 4 \\
\hline & 30 & 338 & $87.79 \%$ & & 4 \\
\hline
\end{tabular}

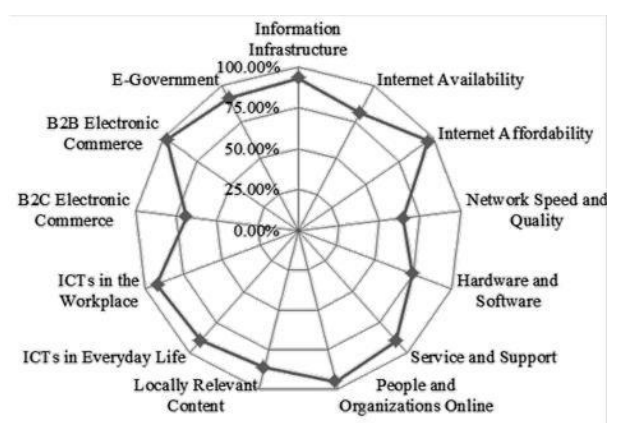

Gambar 1. Diagram Radar Kesiapan per Indikator

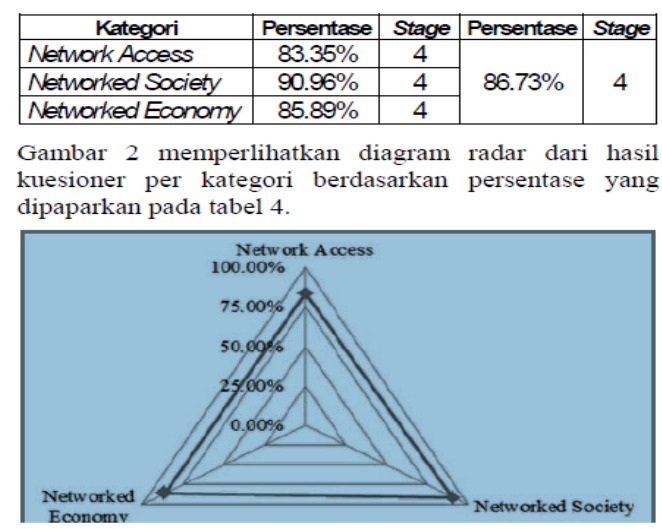

Dari hasil dan pembahasan analisis penelitian, diperoleh persentase rata-rata sebesar $86,73 \%$ atau berada dalam tingkat 4 dalam tingkat kesiapan CID Harvard. Hal ini menunjukkan bahwa pengguna Intranet 
Kemenperin sudah sangat siap untuk aplikasi Intranet berbasis Android di Kemenperin. Akhirnya, sebagai saran kepada Pusdatin (Pusat Datadan Informasi) Kementerian Perindustrian atau peneliti selanjutnya, sebaiknya penelitian ini dilanjutkan dengan perancangan sistem informasi berrbasis android. Ketiga, "ANALISA KESIAPAN INDIVIDU DALAM MENGADOPSI SISTEM INFORMASI MANAJEMEN KEPEGAWAIAN (SIMPEG) STUDI KASUS PADA PEMERINTAH KABUPATEN WONOSOBO"Danu Candra Prabowo1), Wing Wahyu Winarnoz), Silmi Fauziatis)1), 3) Teknik Elektro dan Teknologi Informasi UGM Yogyakarta 2) Akuntansi STIE YKPN Yogyakarta1),3) Jln. Grafika 2 Yogyakarta 55281, 2) Jl. Seturan Raya, Sleman Yogyakarta 55281 Email : danucp@gmail.com1),maswing@gmail.com2), silmi@te.ugm.ac.id3 Abstrak Pengaruh perkembangan Teknologi Informasi dan Komunikasi (TIK) dirasakan di organisasi pemerintah, salah satunya terhadap pelayanan kepegawaian. Untuk dapat melaksanakan pelayanan kepegawaian yang efektif dan efisien dibutuhkan manajemen kepegawaian yang baik dan untuk dapat melaksanakan manajemen kepegawaian yang baik maka solusi yang ditawarkan adalah mengadopsi Sistem Informasi Manajemen Kepegawaian (SIMPEG).Untuk mampu mengadopsi SIMPEG, dibutuhkan kesiapan individu untuk menghadapi perubahan dari mekanisme kerja lama ke mekanisme kerja yang baru.

Penelitian ini bertujuan untuk menganalisa kesiapan individu dalam mengadopsi SIMPEG dilihat dari tingkat keyakinan dan keperibadian inndividu. Teori yang digunakan dalam penelitian ini diadopsi dari Teori Self Efficacy, Technology Readiness Index (TRI) dan pengukuran Readiness for Change. Responden dalam penelitian ini adalah Pegawai Negeri Sipil (PNS) di lingkungan Pemerintah Kabupaten Wonosobo yang ditempatkan di Sub Bagian Kepegawaian di setiap Satuan Kerja Perangkat Daerah (SKPD). Hasil analisis dengan $\alpha=0,05$ menunjukkan bahwa kesiapan individu dalam mengadopsi SIMPEG dipengaruhi secara signifikan oleh sikap optimis, kemauan untuk berinovasi, keyakinan individu untuk bekerja dalam situasi, kondisi dan pekerjaan yang beragam dan rasa ketidakamanan individu terhadap

SIMPEG. Sedangkan rasa ketidaknyamanan dalam penggunaan SIMPEG, tingkat kesulitan pekerjaan, rasa percaya diri tidak berpengaruh secara signifikan terhadap kesiapan individu dalam mengadopsi SIMPEG. Kata kunci : Self Efficacy, Technology Readiness Index,

Readiness for Change, Kesiapan Individu, SIMPEG.

masalah pada penelitian ini adalah untuk mengetahui apakah sikap keyakinan dan keperibadian mempengaruhi kesiapan individu dalam menghadapi perubahan (readiness for change) untuk mengadopsi SIMPEG di Kabupaten Wonosobo ?

Dalam penelitian ini terdapat 3 (tiga) dimensi pembentuk variabel, antara lain dimensi self efficacy dan

technology readiness index sebagai pembentuk variabel eksogen dan dimensi readiness for change sebagai

pembentuk variabel endogen, adapun penjelasan masingdimensi adalah sebagai berikut :

\section{A. Self Efficacy}


Self efficacy diturunkan dari teori kognitif sosial (sosial cognitif theory) yang dinyatakan sebagai kepercayaan seseorang terhadap kemampuan untuk mengerjakan tugas pada tingkatan tertentu. Hal tersebut faktor yang mempengaruhi aktifitas pribadi terhadap pencapaian tugas [1]. Menurut Woolfolk [8], Self efficacy adalah penilaian seseorang terhadap dirinya sendiri atau tingkat keyakinan mengenai seberapa besar kemampuannya dalam mengerjakan suatu tugas tertentu untuk mencapai hasil tertentu. Menurut Bandura [1], ada tiga variabel dari self efficacy, yaitu Level/magnitude, Strength, Generality.Dari variabel tersebut dapat diketahui seberapa besar self efficacy yang dimiliki individu dan variabel mana yang paling berpengaruh terhadap kesiapan individu dalam menghadapi perubahan dan tuntutan organisasi untuk mengadopsi SIMPEG.

\section{B. Technology Readiness Index}

Dalam buku Techno Ready Marketing, Parasuraman [2], mendefinisikan Technology Readines sebagai berikut : "People propensity to embrace and use new technologies for accomplishing goal in home life and work", yang kemudian dikembangkanlah Technology Readiness Index (TRI) sebagai parameter dalam mengukur kesiapan pengguna (individu) dalam mengadopsi teknologi baru. Pengukuran tingkat kesiapan dilakukan dengan mengacu pada empat variabel keperibadian yang ada pada TRI, yaitu Optimisme/optimism, Inovasi/innovativeness,

Ketidaknyamanan/ discomfort, Ketidakamanan/insecurity Dari empat variabel tersebut, optimisme dan inovasi memiliki sifat kontributor, yaitu sifat dapat meningkatkan kesiapan individu dalam menerima teknologi baru.Sedangkan ketidaknyamanan dan ketidakamanan memiliki sifat inhibitor, yaitu sifat yang menekan tingkat kesiapan individu dalam menerima teknologi baru.

C. Readiness for Change Readiness for Change dapat diartikan sebagai kesiapan untuk berubah, yaitu berubah dari metode lama ke metode baru. Kesiapan untuk berubah (readiness for change) merupakan sikap yang komprehensif yang dipengaruhi secara simultan oleh apa yang berubah, bagaimana perubahan tersebut dilakukan, keadaan dimana perubahan tersebut akan berlangsung dan karakteristik dari orang yang diminta untuk melakukannya yang terliputi secara bersama-sama terefleksi ke dalam tingkatan seseorang atau sekelompok orang secara kognitif dan emosional untuk cenderung menerima, embrace dan mengadopsi perubahan yang dipersiapkan yang direncanakan untuk mengganti keadaan saat ini [9]. 


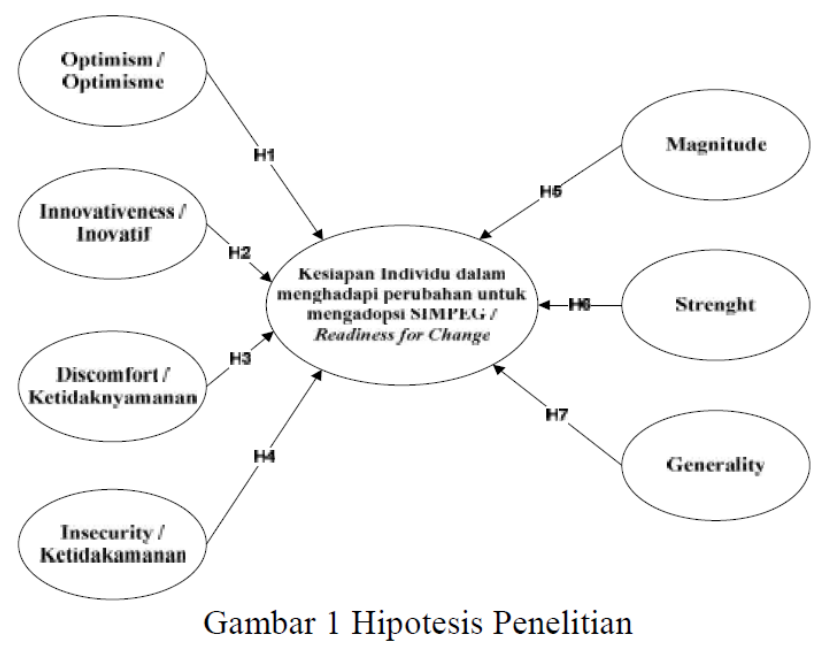

Hipotesis Berdasarkan latar belakang, rumusan masalah, tujuan penelitian dan landasan teori yang ada, maka hiptosis yang dapat diajukan dapat dilihat pada gambar 1.

H1 : Optimism berpengaruh secara signifikan terhadap sikap individu dalam kesiapan menghadapi perubahan untuk mengadopsi SIMPEG (Readiness for Change)

H2 : Innovativeness berpengaruh secara signifikan terhadap sikap individu dalam kesiapan menghadapi perubahan untuk mengadopsi SIMPEG (Readiness forChange)

H3 : Discomfort berpengaruh secara signifikan terhadapsikap individu dalam kesiapan menghadapi perubahanuntuk mengadopsi SIMPEG (Readiness for Change)

H4 : Insecurity berpengaruh secara signifikan terhadapsikap individu dalam kesiapan menghadapi perubahanuntuk mengadopsi SIMPEG (Readiness for Change)

H5 : Magnitude berpengaruh secara signifikan terhadap kesiapan dalam menghadapi perubahan untuk mengadopsi SIMPEG (Readiness for Change)

H6 : Strenght berpengaruh secara signifikan terhadapkesiapan dalam menghadapi perubahan untukmengadopsi SIMPEG (Readiness for Change)

H7 : Generality berpengaruh secara signifikan terhadapkesiapan dalam menghadapi perubahan untukmengadopsi SIMPEG (Readiness for Change)Pada gambar 1 dapat dijelaskan bahwa dimensitechnology readiness index yang terdiri dari 4 (empat)variabel yaitu optimism, innovativeness, discomfort daninsecurity serta dimensi self efficacy yang terdiri dari 3(tiga) variabel yaitu magnitude, strenght dan generality, sebagai variabel eksogen dan variabel readiness forchange sebagai variabel endogen.

Metodologi Penelitian ini mempergunakan metode kuantitatifmelalui kuesioner yang diberikan kepada pegawai yangberada di Sub Bagian Kepegawaian di setiap Instansi di Pemerintah Kabupaten Wonosobo. Kuesioner berisi 28 pertanyaan tertulis yang diisi oleh responden dengan 5 skala likert. Data dianalisis dengan Partial Least Square (PLS) yang merupakan bagian sekaligus alternatif dari Structural Equation Modeling (SEM). Software yangdipergunakan adalah SmartPLS.Hasil PenelitianDari hasil penyebaran kuesioner, didapatkan data variabel dan dianalisis untuk mendapatkan gambaran tentang hasil dari survei responden dengan kuesioner yang telah dilakukan, penjelasannya adalah sebaga berikut : Evaluasi Model Pengukuran (Outer Model) Pada tabel 1 diperlihatkan uji validitas dan uji 
reliabilitas dari instrumen. Pada uji reliabilitas diukur dengan 2 (dua) kriteria, yaitu composite reliability dan croncbach alpha. Namun, composite reliability dinilai lebih baik dalammengestimasi konsistensi internal suatu konstruk [10], sehingga pada penelitian ini, uji konsistensi internal dan kestabilan data menggunakan hasil nilai pada composite reliability.Jika koefisien alpha berada diatas 0,7 dianggap reliabel namun, dengan nilai 0,6 masih cukup reliabel untuk digunakan. Analisis SEM berbasis varian (PLS) digunakan untuk menguji hipotesis, dan penelitian ini menggunakan tingkat signifikan 0,05 atau 5\% untuk dasar penerimaan atau penolakan hipotesis.

Pada tabel 1 dapat dijelaskan, untuk nilai AVE dari masing-masing konstruk bernilai lebih besar dari $\underline{\text { Tabel } 1 \text { Nilai uji validitas dan uji reliabilitas }}$

\begin{tabular}{lcc}
\hline \multicolumn{1}{c}{ Konstruk } & AVE & $\begin{array}{c}\text { Composite } \\
\text { Reliability }\end{array}$ \\
\hline Discomfort & 0,6410 & 0,7792 \\
Generazability & 0,6570 & 0,7892 \\
Innovativeness & 0,5243 & 0,7624 \\
Insecurity & 0,7119 & 0,8313 \\
Magnitude & 0,8330 & 0,9089 \\
Optimism & 0,6610 & 0,7850 \\
Readiness for Change & 0,6597 & 0,8855 \\
Strenght & 0,5540 & 0,7845 \\
\hline
\end{tabular}

0,5 , hal ini mengindikasikan bahwa model yang digunakan memiliki tingkat validitas diskriminan yang tinggi. Nilai AVE dapat dihitung dengan menggunakan persamaan berikut ini :

Nilai Composite Reliability dari masing-masing konstruk bernilai lebih besar dari 0,7, mengindikasikan

$$
A V E=\frac{\left(\sum \lambda i^{2}\right)}{\left(\sum \lambda i^{2}\right)+\sum\left(1-\overline{\lambda i^{2}}\right)}
$$

Dimana $\lambda i$ adalah component loading indikator dan var

$$
\left(1-\lambda i^{2}\right) \text {. }
$$

model yang digunakan memiliki alat ukur yang konsisten. Nilai Composite Reliability dapat dihitung dengan menggunakan persamaan berikut ini :

$$
\rho c=\frac{\left(\sum \lambda i\right)^{2}}{\left(\sum \lambda i\right)^{2}+\overline{\Sigma(1}\left(1-\overline{\left.\lambda i^{2}\right)}\right.}
$$

Dimana $\lambda i$ adalah component loading indikator dan var $\left(1-\lambda i^{2}\right)$.

Dalam uji validitas dan uji reliabilitas, dapat disimpulkan bahwa model dalam penelitian kesiapan individu dalam mengadopsi SIMPEG adalah layak dan dapat diterima. Evaluasi, Model Struktural (Inner Model) Model struktural dievaluasi dengan menggunakan Rsquare 
untuk variabel dependen, nilai path coefficients $(\beta)$ atau $t$-values tiap path untuk menguji signifikansiantar konstruk dalam model struktural[11]. Nilai R-square Semakin tinggi nilai R-square, maka semakin besar variabel independen tersebut dapat menjelaskan variabel dependen, sehingga semakin baik persamaan struktural[11]. Pada Tabel 4 menunjukkan R-square.

Konstruk readiness for change memiliki $R$-Square sebesar 0,6824 yang berarti bahwa variansi pada Tabel 2 Nilai $R$-Square

\begin{tabular}{ll}
\hline Konstruk & R Square \\
\hline Discomfort & 0 \\
Generality & 0 \\
Innovativeness & 0 \\
Insecurity & 0 \\
Magnitude & 0 \\
Optimism & 0 \\
Readiness for Change & 0,6824 \\
Strenght & 0 \\
\hline
\end{tabular}

konstruk readiness for change dapat dijelaskan oleh konstruk discomfort, generality, innovativeness, insecurity, magnitude, optimism dan strenght sebesar 68,24 \%. Sementara 31,76\% lainnya dijelaskan oleh variabel lain di luar model. Pengujian Hipotesis

Pengujian hipotesis dalam penelitian ini menggunakan tingkat signifikansi (significant level) 5\% dan tingkat keyakinan (confidence level) 95\%. Nilai Ttable dengan tingkat siginifikasi 95\% adalah 1,96. Agar suatu hipotesis diterima maka T-statistics > 1,96. Tabel 3 memperlihatkan hasil path coefficients dan T-statistics yang dapat dijelaskan sebagai berikut. Sikap Optimis (Optimism) adalah sikap pandangan positif terhadap teknologi baru yang merubah kinerja mereka akan semakin baik dan percaya bahwa SIMPEG akan meningkatkan kontrol, fleksibilitas dan efiseiensi dalam proses pengolahan data pegawai. Optimis dimungkinkan dipengaruhi oleh faktor usia, Febriandy [11] meng-kategorikan usia sesorang terhadap sikap

optimis. Rentang usia 20-35 merupakan masa produktif dalam penyerapan ilmu pengetahuan, dengan adanya ilmu pengetahuan dan pengalaman yang mereka miliki akan berdampak pada sikap optimis bahwa apa yang mereka lakukan akan berdampak positif. Korelasi yang dibentuk menggambarkan bahwa semakin tinggi sikap optimis, maka semakin tinggi pula tingkat kesiapan dalam mengadopsi SIMPEG. Sikap inovatif (Innovativeness) dibutuhkan dalam mengadopsi SIMPEG, karena seseorang yang inovatif menyadari bahwa perkembangan teknologi sangat cepat sehingga timbul pula anggapan bahwa daur hidup temuan-temuan dibidang sistem teknologi informasi juga sangat cepat. Faktor jenis kelamin kemungkinan berpengaruh terhadap sikap inovatif. Berdasarkan data jenis kelamin responden, 58\% adalah laki-laki yang artinya laki-laki akan melakukan apa saja untuk mencapai kesuksesan, termasuk untuk bertindak kreatif dan inovatif [12]. Hal ini bertentangan dengan penelitian Dada [6], yang menyatakan perbedaan gender tidak berpengaruh secara signifikan dalam mengadopsi 
teknologi.Keempat, “TINGKAT KESIAPAN (READINESS) IMPLEMENTASI E-LEARNING DI SEKOLAH MENENGAH ATAS KOTA YOGYAKARTA THE READINESS LEVEL OF IMPLEMENTING E-LEARNING IN YOGYAKARTA HIGH SCHOOLS” Nur Hadi Waryanto, Nur Insani Jurusan Pendidikan Matematika FMIPA UNY

E-mail : nurhadiw@gmail.com. Abstrak Tujuan penelitian adalah untuk mengetahui tingkat kesiapan sekolah dan mengungkap faktor atau area mana yang masih lemah dan memerlukan perbaikan dan area

Tabel 3. Analisis T-Statistik Path Coefficients Hipotesis

\begin{tabular}{cllll}
\hline \multirow{2}{*}{ Hipotesis } & \multicolumn{1}{c}{ Dari } & \multicolumn{1}{c}{ Path / Jalur } & $\begin{array}{c}\text { T Statistics } \\
(|\mathrm{O} / \mathrm{STERR}|)\end{array}$ & \multicolumn{1}{c}{ Hasil Pengujian $\alpha=5 \%$} \\
\hline H1 & Optimism & Readiness for Change & $\mathbf{1 , 9 8 5 7 ^ { * }}$ & Signifikan \\
H2 & Innovativeness & Readiness for Change & $\mathbf{3 , 1 7 6 3 ^ { * }}$ & Signifikan \\
H3 & Discomfort & Readiness for Change & 0,4423 & Tidak Signifikan \\
H4 & Insecurity & Readiness for Change & $\mathbf{3 , 5 6 7 9 ^ { * }}$ & Signifikan \\
H5 & Magnitude & Readiness for Change & 1,3316 & Tidak Signifikan \\
H6 & Strenght & Readiness for Change & 0,4376 & Tidak Signifikan \\
H7 & Generality & Readiness for Change & $\mathbf{3 , 1 3 0 4 *}$ & Signifikan \\
\hline
\end{tabular}

mana yang sudah dianggap berhasil atau kuat dalam mendukung penerapan e-learning dalam proses pembelajaran. Model yang digunakan adalah menggunakan model ELR Chapnick yang menggunakan delapan faktor readiness untuk mengukur ELR, yaitu psychological readiness, sociological readiness, environmental readiness, human resource readiness, financial readiness, technological skill (aptitude) readiness, equipment readiness, dan content readiness. Model Chapnick akan memberikan hasil berupa skor yang dapat menentukan peringkat kesiapan e-learning suatu sekolah. Hasil penelitian menunjukkan bahwa e-learning readiness SMA Kota Yogyakarta mempunyai skor 103,76. Skor ini menurut model Chapnick masuk dalam kategori cukup siap. Kategori yang mempunyai skor e-learning readiness yang tinggi adalah kategori sociological readiness. Berdasarkan model Chapnick, skor ELR yang masuk dalam kategori siap adalah sociological readiness, enviromental readiness, human resource readiness, technological readiness, dan content readiness.

Kata kunci: readiness, ELR, e-learning. Tujuan penelitian ini adalah (1) menge-tahui tingkat kesiapan (e-readiness) untuk pe-nerapan e-learning dalam proses pembelajaran di Sekolah Menengah Atas di Kota Yogyakarta dan (2) mengungkap faktor atau area mana yang masih lemah dan memerlukan perbaikan dan area mana sudah dianggap berhasil atau kuat dalam mendukung penerapan e-learning dalam proses pembelajaran.

Agar penerapan e-learning dalam proses pembelajaran di sekolah dapat berjalan dengan sukses, perlu dilakukan evaluasi untuk menge- tahui tingkat kesiapan sekolah untuk pene-rapan e-learning dalam proses pembelajaran di sekolah.

Evaluasi digunakan untuk memotret profil dan kapasitas TI di sekolah tersebut dan mengevaluasi kecukupannya untuk mencapai tujuan. Dari hasil evaluasi tersebut akan dike-tahui tingkat kesiapan sekolah dalam penera-pan e-learning.

Komponen utama yang membentuk e-learning menurut R. S. Wahono (2009) adalah Infrastruktur Elearning dan system dan apli-kasi e-learning. Infrastruktur e-learning dapat berupa personal computer (PC), jaringan kom-puter, internet dan perlengkapan multimedia, termasuk di dalamnya peralatan 
teleconference apabila kita memberikan layanan synchronous learning. Sistem dan Aplikasi E-learning dapat memvirtualisasi proses pembelajaran konvensional, bagaimana manajemen kelas, pembuatan materi atau konten, forum diskusi, sistem penilaian (rapor), sistem ujian online dan segala fitur yang berhubungan dengan manajemen proses pembelajaran. Sistem perangkat lunak tersebut sering disebut dengan Learning Management System (LMS).

Menurut R. S. Wahono (2009) terdapat beberapa organisasi dan konsorsium yang me-ngeluarkan standar dalam dunia e-learning di-antaranya adalah sebagai berikut.

1. Advanced Distributed Learning (ADL) (http://adlnet.org)

2. Aviation Industry CBT Committee (AIC-C) (http://aicc.org)

3. IMS Global Consortium (IMS) (http:// imsproject.org)

4. IEEE Learning Technology Standards

Committee (IEEE LTSC) (http://ltsc.ieee. org)

Salah satu standar yang diterima banyak pihak adalah yang dikeluarkan ADL, yaitu Shareable Content Object Reference Model (SCORM). Spesifikasi SCORM mengkom-binasikan elemen-elemen dari spesifikasi standar yang dikeluarkan oleh IEEE, AICC dan IMS. SCORM memungkinkan pengem-bang dan penyedia konten e-learning lebih konsisten dan mudah dalam implementasi karena sifat SCORM yang reusable. Standar SCORM berkembang dari versi SCORM 1.0, SCORM 1.1, SCORM 1.2, SCORM 2004. Saat ini sudah banyak Learning Management System (LMS) yang mendukung SCORM, termasuk di dalamnya adalah a Tutor dan Moodle untuk yang open source, dan intra-Learn untuk produk komersial (R. S. Wahono, 2009). SCORM memungkinkan untuk mela-kukan impor dan ekspor konten (bahan ajar) yang sudah dibuat di LMS ke LMS lain dengan mudah.

Dalam implementasi e-learning, perlu diketahui terlebih dahulu e-learing readiness (ELR). Borotis \& Poulymenakou (Priyanto, 2008) mendefinisikan e-learning readiness (ELR) sebagai kesiapan mental atau fisik suatu organisasi untuk suatu pengalaman pembelaja-ran. Model ELR dirancang untuk menyeder-hanakan proses dalam memperoleh informasi dasar yang diperlukan dalam mengembangkan e-learning.

Organisasi Web Forum mengeluarkan laporan Global Information Technology Re-port (GITR) yang berisi analisis terkait dengan kekuatan dan kelemahan TIK di suatu negara serta evaluasi terhadap perkembangannya (Yudi Prayudi, 2009). Laporan yang dikeluar-kan dalam GITR ini menggunakan parameter Networked Readiness Index (NRI) yang memuat 3 komponen utama sebagai alat ukur, yaitu (1) lingkungan ICT yang tersedia baik dalam lingkup negara atau komunitas, (2) ke-siapan pelaku utama ICT baik secara individu, bisnis ataupun pemerintahan, dan (3) penggu-naan ICT di kalangan stakeholder. Salah satu model evaluasi yang dikenal luas adalah Kirkpatrick Model yang dikemu-kakan oleh Donald Kirkpatrick (Yudi Prayudi, 2009). Dalam model ini, Kirkpatrick membagi evaluasi elearning dalam empat level yaitu: reaction, knowledge, behavior dan result. Empat level ini lebih menggambarkan evaluasi terhadap output yang didapat oleh suatu insti-tusi setelah 
mengimplementasikan e-learning. Pada masing-masing level terdapat sejumlah assessment yang dapat dijadikan sebagai informasi bagi karakteristik masing-masing level.

Selain itu juga terdapat Model SORT (Student Online Readiness Tools) yang dikem-bangkan University System Of Georgia, seba-gai upaya untuk kategorisasi kesiapan maha-siswa dalam dalam berinteraksi dengan sistem online yang diterapkan pada model pembela-jarannya (Yudi Prayudi, 2009).

Model lain yang adalah RILO (Readiness Index for Learning Online) yang dikembang-kan oleh Indiana University School of Nursing (http://online.southeast.edu/onlinereadinesssurvey/) (Yudi Prayudi, 2009). RILO berisi sejumlah assessment yang mengarah pada per-tanyaan dasar kepada calon mahasiswa yang akan mengambil course secara online.

Model e-learning Readiness Index (eLRI) adalah model evaluasi untuk mengukur sejauh aspek-aspek yang terlibat dalam imple-mentasi e-learning telah sesuai dengan tujuan awalnya (Yudi Prayudi, 2009). Pada prinsip-nya, model yang dibangun untuk eLRI dapat dianalogikan dengan model pengukuran Networked Readiness Index (NRI).

Chapnick (2000) mengusulkan model ELR dengan mengelompokkan kesiapan ke dalam delapan kategori kesiapan, yaitu seba-gai berikut.

1. Psychological readiness

Faktor ini mempertimbangkan cara pan-dang individu terhadap pengaruh inisiatif e-learning. Ini adalah faktor yang paling penting yang harus dipertimbangkan dan memilki peluang tertinggi untuk sabotase proses implementasi.

2. Sociological readiness

Faktor ini mempertimbangkan aspek in-terpersonal lingkungan di mana program akan diimplementasikan. 3. Environmental readiness

Faktor ini mempertimbangkan operasi kekuatan besar pada stakeholders, baik di dalam maupun di luar organisasi.

4. Human resource readiness

Faktor ini mempertimbangkan ketersedia-an dan rancangan sistem dukungan sum-ber daya manusia.

5. Financial readiness

Faktor ini mempertimbangkan besarnya anggaran dan proses alokasi.

6. Technological skill (aptitude) readiness

Faktor ini mempertimbangkan kompeten-si teknis yang dapat diamati dan diukur.

7. Equipment readiness

Faktor ini mempertimbangkan kepemili-kan peralatan yang sesuai.

8. Content readiness

Faktor ini mempertimbangkan konten pembelajaran dan sasaran pembelajaran.

Model ELR akan menghasilkan skor yang dapat menentukan peringkat kesiapan e-learning suatu lembaga. Siapapun yang me-ngembangkan, model ELR dapat membantu pimpinan tidak hanya untuk mengukur tingkat kesiapan lembaga untuk mengimplementasi-kan e-learning, tetapi yang lebih penting 
ada-lah mengungkap faktor atau area mana masih lemah dan memerlukan perbaikan dan area mana sudah dianggap berhasil atau kuat dalam mendukung implementasi e-learning. METODE PENELITIAN Penelitian ini adalah penelitian deskrip-tif yang secara mendasar adalah penelitian yang bermaksud untuk membuat deskripsi mengenai situasi-situasi atau kejadian-kejadi-an. Metode penelitian ini adalah metode survei. Metode survei dalam penelitian ini dibatasi pada survei sampel dari populasi untuk mewakili seluruh populasi. Menurut Suryobroto (Zulfiana Farista, 2007), tujuan metode survei adalah untuk mengetahui informasi aktual yang mendetail yang men-deskripsikan gejala yang ada, mengidentifikasi masalah, membuat komparasi dan evaluasidan untuk mengetahui apa yang dilakukan orang lain dalam menangani masalah atau situasi yang sama untuk kepentingan pembuatan rencana dan pengambilan keputusan di masa yang akan datang. Penelitian dilaksanakan pada AgustusSeptember 2013 di sebanyak 9 SMA negeri di Kota Yogyakarta.

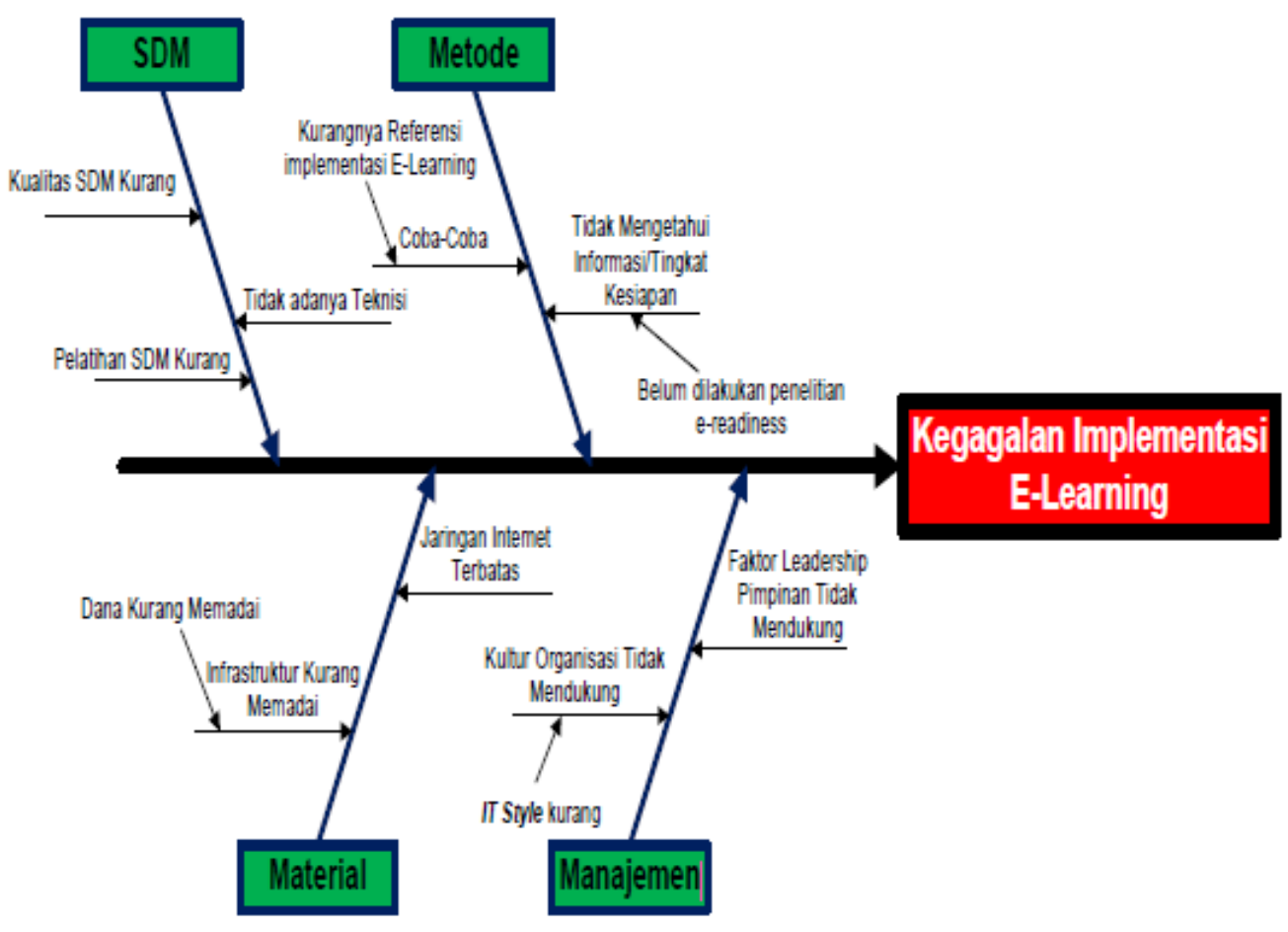

Gambar 1. Diagram Fishbone Masalah Penelitian

Model yang digunakan adalah model ELR Chapnick yang menggunakan delapan faktor readiness untuk mengukur ELR. Model Chapnick akan memberikan hasil berupa skor yang dapat menentukan peringkat kesiapan e-learning suatu sekolah. Model ini dipilih ka-rena dapat digunakan sebelum penerapan $e$ learning dalam proses pembelajaran. Selain itu ELR Model Chapnick dapat digunakan secara terus menerus untuk menjaga keber-langsungan program penerapan e-learning dalam proses pembelajaran. Model ini hanya memfokuskan pada aspek institusi dalam hal ini adalah guru. HASIL DAN PEMBAHASAN Sesuai dengan lokasi penelitian yang telah ditentukan, pengambilan data dilakukan di 11 SMA Negeri di Kota Yogyakarta. Adapun realisasi lokasi SMA yang dijadikan tempat untuk pengambilan data seperti terlihat di Tabel 1. 
Tabel 1. Jumlah Sekolah Sampel

\begin{tabular}{lcc}
\hline & Jumlah & Persentase \\
\hline Target SMA Sampel & 11 & $100 \%$ \\
Realisasi & 9 & $81,82 \%$ \\
\hline
\end{tabular}

Berdasarkan Tabel 1, pengambilan data dilakukan di 9 SMA dari 11 SMA yang direncanakan atau terealisasi sebesar $81,82 \%$. Hal ini disebabkan terdapat 2 SMA yang menolak untuk dijadikan lokasi pengambilan data karena ada kebijakan dari kepala sekolah untuk me-nolak ijin dijadikan lokasi pengambilan data. Alasan adanya kebijakan tersebut diantaranya adalah kesibukan dari guru dan kepala sekolah SMA, dalam waktu yang bersamaan pihak sekolah telah menerima banyak usulan penelitian.Hasil E-learning Readiness Score untuk SMA negeri di Kota Yogyakarta disajikan pa-da Tabel 2. Pergeseran paradigma sistem pembela-jaran mulai nampak pada proses transfer pengetahuan. Proses

Tabel 2. E-learning Readiness Score SMA

\begin{tabular}{clc}
\multicolumn{3}{c}{ Negeri di Kota Yogyakarta } \\
\hline No & Kategori ELR & Skor \\
\hline 1 & Psychological & 15.81 \\
2 & Sociological & 11.44 \\
3 & Environmental & 16.78 \\
4 & Human resource & 8.02 \\
5 & Financial & 7.29 \\
6 & Technological skill & 12.94 \\
7 & Equipment & 15.11 \\
8 & Content & 16.38 \\
\hline & Total & 103.76 \\
\hline
\end{tabular}

pembelajaran yang ada sekarang ini cenderung lebih menekankan pada proses mengajar (teaching), berbasis pada isi (content base), bersifat abstrak dan hanya untuk golongan tertentu (pada proses ini pembelajaran cenderung pasif). Seiring per-kembangan ilmu dan teknologi ICT, proses pembelajaran mulai bergeser pada proses belajar (learning), berbasis pada masalah (case base), bersifat kontekstual dan tidak terbatas hanya untuk golongan tertentu. Pada proses pembelajaran seperti ini siswa dituntut untuk lebih aktif dengan mengoptimalkan sumber-sumber belajar yang ada. Sampai sekarang masih belum ada stan-dart yang baku baik dalam hal definisi maupun implementasi e-learning. Hal ini menjadikan banyak orang mempunyai konsep yang bermacam-macam. E-learning merupakan kependekan dari electronic learning. Salah satu definisi umum dari e-learning diberikan oleh Gilbert \& Jones (Herman Surjono 2007), yaitu: pengiriman materi pembelajaran melalui suatu media elektronik seperti Internet, intranet/extranet, satelit, broadcast, audio/ video tape, interactive TV, CDROM, dan Computer-Based Training (CBT).

Priyanto (2008) menjelaskan bahwa pe-nerapan e-learning melibatkan beberapa aspek yaitu: (1) infrastruktur teknologi; (2) sumber daya; dan (3) lingkungan. Setiap entitas memiliki peran yang berbeda tetapi konvergen untuk menciptakan suatu sistem. Infrastruktur teknologi terdiri atas hardware dan software. Hardware meliputi ketersediaan komputer, jaringan intranet, dan koneksi internet. Learning Management System (LMS) merupakan software utama untuk e-learning yang dirancang untuk menangani proses komunikasi antara dosen dan mahasiswa dalam proses pembelajaran. Untuk 
menangani infrastruktur teknologi ini diperlukan unit khusus (administrator) yang memberi layanan teknis untuk menangani sistem secara keseluruhan dan berkelanjutan.

Sumber Daya Manusia terdiri dari Guru dan siswa. Guru bertugas untuk menyediakan konten pembelajaran dalam format digital dan melakukan evaluasi. Siswa bertugas untuk mengakses konten pembelajaran, menger-jakan tugas, dan mengerjakan tes. Lingkungan menurut Psycharis (Priyanto, 2008) yang terdiri atas kepemimpinan dan kultur, merupakan faktor yang sangat penting dalam kesuksesan e-learning. Di sini peran pemim-pin sangat penting dalam menciptakan kultur yang kondusif dalam imlementasi e-learning, bukan sebaliknya, kultur menciptakan kepe-mimpinan.

Chapnick dan Aydm (Priyanto, 2008) memperingatkan bahwa harus berhati-hati da-lam proses adopsi e-learning untuk suatu organisasi. Pada penerapan e-learning diper-lukan data prakondisi sebelum program diterapkan. Tahap analisis bertugas menyiap-kan data prakondisi yang mencakup semua aspek yang akan mempengaruhi keberhasilan e-learning, diwujudkan dalam dokumen ana-lisis kebutuhan. Chapnick (2000) menyatakan bahwa sebelum mengimplementasikan pro-gram e-learning, organisasi perlu melakukan analisis kebutuhan dengan memuat dukumen kebutuhan (requirements document) yang mencakup: (1) sasaran (sasaran makro organi-sasi dan sasaran mikro pembelajaran); (2) skor kesiapan e-learning; (3) daftar keuntungan dan kendala dalam mengadopsi e-learning; dan (4) daftar kemungkinan konfigurasi e-learning. Dari skor kesiapan e-learning tahap analisis di-peroleh area mana yang dipandang sudah siap dan area mana yang lemah, data ini digunakan sebagai base line untuk tahap berikutnya.

Berdasarkan hasil konversi skala peni-laian ELR Model Chapnick, maka dapat dianalis sebagai berikut. Untuk SMA Negeri kategori yang mempunyai tingkat kesiapan tinggi adalah kategori sociological readiness, enviromental readiness, human resource rea-diness, dan technological skill readiness, content readiness.

Berdasarkan hasil konversi skala penila-ian ELR Model Chapnick (Tabel 3), maka da-pat dianalis sebagai berikut.

1. Berdasarkan skor tingkat kesiapan dari delapan kategori ELR tersebut didapat skor total E-learning Readiness untuk SMA di Kota Yogyakarta sebesar 103,76. Dapat dikatakan bahwa SMA di kota Yogyakarta cukup siap untuk implemen-tasi E-learning.

2. Kategori yang mempunyai tingkat kesia-pan tinggi adalah kategori sociological readiness.Hal ini berkaitan dengan faktor yang mempertimbangkan aspek interper-sonal lingkungan di mana program akan diimplementasikan. 
3. Kategori yang mempunyai tingkat kesia-pan cukup adalah Psychological readi-ness, financial readiness, equipment rea-diness, content readiness.

Tabel 3. Tingkat Kesiapan SMA Negeri Kota

\begin{tabular}{clcl}
\multicolumn{5}{c}{ Yogyakarta } \\
\hline No & Kategori ELR & Skor & Keterangan \\
\hline 1 & Psychological & 15.81 & Cukup Siap \\
2 & Sociological & 11.44 & Siap \\
3 & Environmental & 16.78 & Siap \\
4 & Human resource & 8.02 & Siap \\
5 & Financial & 7.29 & Cukup Siap \\
6 & Technological skill & 12.94 & Siap \\
7 & Equipment & 15.11 & Cukup Siap \\
8 & Content & 16.38 & Siap \\
\hline & Total & 103.76 & Cukup Siap \\
\hline
\end{tabular}

Human Resource Readiness masuk da-lam kategori siap, hal ini berarti pertimbang-kan ketersediaan dan rancangan sistem duku-ngan sumber daya manusia sudah memadai. Tingkat kesiapan Human Resource dapat juga dilihat dari tingkat pendidikan guru di sekolah tersebut yang minimal sarjana bahkan banyak juga yang sudah S2, hal ini memberikan dukungan untuk tingginya tingkat kesiapan kategori human resource.

Model e-learning readiness menjadi instrumen yang sangat efektif untuk mela-kukan evaluasi efektifitas strategi organisasi dalam mengembangan e-learning dan sebagai dasar evaluasi dari efektifitas program e-learning. Model e-leaning readiness dipan-dang tepat sebagai instrumen yang "meng-awal" perjalanan pengembangan e-learning dari tahap analisis sampai pada tahap evalua-si.

Priyanto (2008) mengemukanan bahwa model e-learning readiness dapat digunakan sebagai instrumen evaluasi. Dari hasil evalu-asi dapat diketahui apakah implementasi e-learning berhasil atau gagal, dilihat dari adanya peningkatan skor atau tidak. Dari hasil evaluasi dapat dideteksi apakah area yang lemah sudah dapat diperbaiki. Hasil evaluasi ini selanjutnya digunakan sebagai recycling decission untuk proses perbaikan pada perio-de berikutnya. Model ELR tidak hanya digu-nakan selama proses pengembangan, atau se-lama periode hibah (misal dua tahun), tetapi sebaiknya digunakan secara terus menerus un-tuk menjaga keberlangsungan program adopsi e-learning.

Berdasarkan analisis dan konversi skor penilaian ELR tidak ditemukan area atau kate-gori yang mempunyai tingkat kesiapan rendah atau tidak siap. Dari hasil konversi skala peni-laian ELR, SMA di kota Yogyakarta dalam pe-nerapan e-learning dalam proses pembelajaran minimal memperoleh skala penilaian cukup si-ap. Walaupun tidak ada area yang mempunyai skala penilaiannya tidak siap, tetap akan di-uraikan rekomendasi bagi sekolah untuk dapat meningkatkan skor ELR karena model ini dapat digunakan secara terus menerus untuk menjaga keberlangsungan program penerapan e-learning dalam proses pembelajaran.Kelima, "Pengukuran Kesiapan Sumberdaya Pembelajaran Pada Implementasi Pendidikan Jarak Jauh (E-Learning Readiness) di IKPIA Perbanas

Studi kasus Fakultas FTI’' Deden Prayitno 1), Elliana Gautama2), Riska Hanifah3) 
1), Prodi Sistem Komputer, FTI, Perbanas Institut,Jl. Perbanas, Karet Kuningan, Setiabudi, Jakarta, Indonesia 2), 3) Prodi Sistem Informasi, FTI, Perbanas Institut,Jl. Perbanas, Karet Kuningan, Setiabudi.Jakarta, Indonesia.

International Conference for Emerging Markets (ICEM 2013) - Yogyakarta, 27 November 2013 .

Abstrak - Setelah berdiri lebih dari 40 tahun, IKPIA Perbanas secara berkesinambungan terus melakukan berbagai terobosan, diantaranya pada tahun 2009 menciptakan visi baru, yaitu ingin menjadi lima (5) perguruan tinggi terkemuka di Asia pada tahun 2019. Salah satu langkah yang dilaksanakan adalah mengembangkan strategi pembelajaran, Pengembangan strategi dilakukan untuk mendapatkan cara terbaik dalam proses pembelajaran yang dapat meningkatkan prestasi mahasiswa dan lulusan sehingga memiliki daya saing yang tinggi. Saat ini media dan hasil evaluasi pembelajaran telah menggunakan Teknologi Informasi dan Komunikasi (TIK) dengan online system berbasis internet. Untuk rencana belajar dan hasil nilai belajar sudah menggunakan aplikasi online (aplikasi star), tetapi untuk pembelajaran belum optimal, karena sampai saat ini masih pada tahap menggunakan fasilitas internet untuk tugas dan bahan ajar lewat e-mail, chat, forum, groups, belum sampai pada system aplikasi e-learning seutuhnya.Masalah yang muncul dalam penelitian ini adalah: a. Bagaimana mengukur tingkat kesiapan sumber daya pembelajaran dalam merencanakan penerapan Pembelajaran Jarak Jauh (PJJ) dapat dilakukan? b. Bagaimana melakukan perencanaan penerapan PJJ agar dapat memberikan kontribusi positip terhadap peningkatan prestasi mahasiswa dan meningkatkan daya saing yang tinggi c. Bagaimana sebaiknya Pembelajaran Jarak Jauh (PJJ) diterapkan agar dapat memberikan kontribusi positip terhadap peningkatan prestasi mahasiswa dan meningkatkan daya saing yang tinggi? Untuk memecahkan masalah tersebut maka dibuatlah Konsep Pendidikan Jarak Jauh (PJJ)

Konsep Pendidikan Jarak Jauh secara konseptual, dapat dilihat dari dua aspek, yaitu aspek institusional dan aspek personal. Aspek institusional, aspek ini berkenaan dengan tugas dan kewenangan institusi/lembaga penyelenggara PJJ untuk mengembangkan sistem, desain, mekanisme atau proses yang dibutuhkan oleh peserta didik agar komunikasi dan interaksi pembelajaran dapat terjadi. Dari aspek ini, PJJ dapat dimaknai sebagai "sebuah sistem dan proses pendidikan yang antara pendidik dan peserta didik terpisahkan oleh ruang dan waktu, dan pembelajarannya menggunakan multimedia dan multisumber" (Permendiknas No.24/2012; Wikipedia,2012). Secara institusional PJJ merupakan bidang pendidikan yang memfokuskan pada peran institusi/lembaga penyelenggara PJJ dalam memilih dan pemanfaatan metode dan teknologi pembelajaran yang dapat memfasilitasi "ketidakhadiran atau keterpisahan fisikal" peserta didik di dalam kelas seperti lazimnya di dalam pendidikan konvensional. Fokus kajian PJJ dalam hal ini adalah pada medium teknologi, seperti media cetak, video, komputer, internet, dan lain-lain untuk mendukung implementasi PJJ (Gunawardena \& McIsaac, 2004; Keegan, 1990).

Dalam melakukan pengukuran kesiapan, menggunakan model indeks yang diambil dari Aydin \& Tasci (2005), yaitu:

1. Indeks $1-2.59$ ada pada Not Ready, membutuhkan persiapan banyak untuk menerapkan e-learning 
2. Indeks 2.6 - 3.39 ada pada Not Ready, hanya membutuhkan persiapan beberapa aspek saja

3. Indeks 3.4 - 4.19 ada pada Ready, memerlukan improvement untuk menerapkannya.

4. Indeks 4.2 - 5 ada pada Ready, menyatakan kesiapan yang sudah baik untuk menerapkan e-learning Metodologi Penelitian,Objek yang diteliti adalah sumber daya pembelajaran yang ada di kampus IKPIA Perbanas.Penelitian dilakukan untuk mengetahui tingkat kesiapan dari sumber daya pembelajran yang ada dalam mempersiapkan penerapan e-learning secara utuh.Sumber daya tersebut adalah infrastruktur, sumber daya manusia, materi pembelajaran dan system prosedur yang berjalan.Pendekatan penelitian adalah dengan metoda deskriptif dan teknik pengumpulan data dengan survey research (penelitian survey).Hasil dari penelitian tersebut adalah

1. Sumber daya manusia (dosen, mahasiswa dan karyawan yang terkait) yang ada di lingkungan FTI telah memahami dan mengerti dan siap menerapkan e-learning ( Ready go)

2. Penerapan e-learning dilakukan dengan model dualmode, yaitu menerapkan pada beberapa mata kuliah yang siap sementara mata kuliah lainnya dilaksanakan secara konvensional

3. Indeks kesiapan penerapan e-learning hasil perhitungan adalah 4.21, artinya siap menerapkan elearning (menggunakan Indeks Aydin dan Tasci)

4. Hasil perhitungan dari hampir seluruh variabel yang dikaji, menyatakan siap untuk menerapkan system pembelajaran dengan menggunakan e-learning

\section{Reference}

[1] A. Sanusi, 2011, Metodologi Penelitian Bisnis, Salemba Empat,Jakarta.

[2] Ghozali, L., 2008. Model Persamaan Struktural : Konsep dan Aplikasi Program AMOS 16.0, Badan Penerbit Universitas Diponegoro, Semarang.

[3] I. Ghozali, and Fuad, 2008, Structural Equation Modeling, Badan Penerbitan Universitas Diponegoro, Semarang.

[4] Jogiyanto. 2007. Model Kesuksesan Sistem Teknologi . Yogyakarta : Andi

[5] J. Rose, and G. Fogarty, 2010, Technology Readiness and Segmentation Profile of Mature Consumers. Academy of World Business, Marketing \&Management Development, vol. 4

[6] M. Singarimbun, dan S. Efendi, 2011, Metode Penelitian Survai, Pustaka LP3ES

[7] Rahayudi B dan Sukoharsono EG, 2008, Pengaruh Kompetensi Teknologi Informasi Terhadap Keberhasilan Penerapan Sistem Informasi, KURSOR

[8] Zainal A. Hasibuan, 2007, Metodologi Penelitian Pada Bidang Ilmu Komputer Dan Teknologi, Fakultas Komputer, Universitas Indonesia

[9] Pasuraman A, 2000, Technology Readiness Index (TRI): A Multipleitem Scale To Measure Readiness To Embrace New Technologies, Journal Of Service Research 2:307

[10] N. Anggraeni, Pengaruh Kemampuan dan Motivasi Terhadap Kinerja Pegawai pada Sekolah Tinggi Seni Indonesia (STSI) Bandung. Jurnal UPI, 2011, vol. 12 
[11] Aydin \& Tasci, "Measuring Readiness for e-learning: Reflections form an Emerging Country", International Forum of Educational Technology \& Society (IFETS), 2005

[12] Farisi, Mohammad Imam, Dr., M.Pd., Konsep Belajar Jarak Jauh dan Aplikasinya.

Diunduh dari http://utsurabaya.files.wordpress.com/2012/06/sbjj2.pdf tanggal akses 13 Maret 2013.

[13] Farisi, M.I. (2010). The paradigm shifts in integrating technology at distance education and the structure of teacher's competencies in the field of educational technology. Prosiding International Seminar on Integrating Technology into Education. Jakarta: IPTPI.

[14] Gondodiyoto, S. 2007. Audit Sistem Informasi: Pendekatan Cobit, Edisi Revisi. Jakarta: Mitra Wacana Media

[15] Gunawardena, C.N., \& McIsaac, M.S. (2004). Distance education. In D. H.

[16] Indrajit, R.E. 2004. Kajian Strategis Cost Benefit Teknologi Informasi. Yogyakarta: Penerbit Andi.

[17] Jonassen (Ed.), Handbook of research on educational communications and technology (2nd ed., pp. 355-395). Mahwah, NJ: Lawrence Erlbaum.

[18] Kadarko, W. (1999). Kemampuan belajar mandiri dan faktor-faktor psikososial yang mempengaruhinya: Kasus universitas terbuka. Jurnal Pendidikan Tinggi Jarak Jauh. Volume $1(1)$.

[19] Keegan, D. (1990). Foundations of distance education. 2nd ed. London: Routledge. [20]Maniah dan Surendro, K. 2005. Usulan Model Audit Sistem Informasi (Studi Kasus: Sistem Informasi Perawatan Pesawat Terbang. Seminar Nasional Aplikasi Teknologi Informasi 2005 (SNATI 2005). Yogyakarta.

[21] Moore, M.G. (1972). Learner autonomy: The second dimension of independent learning. Convergence 5(2), 76-88.

[22] Pederiva, A. 2003. The COBIT Maturity Model in a Vendor Evaluation Case.

Information Systems Audit and Control Association.

[23] Sarno, Riyanarto. 2009. Audit Sistem \& Teknologi Informasi. Surabaya: ITS Press.

[24] Sugilar (2000). Kesiapan belajar mandiri peserta pendidikan jarak jauh. Jurnal Pendidikan Tinggi Jarak Jauh. Volume 1(2).

[25] Wedemeyer, C. A., \& Childs, G.B. (1961). New Perspectives in University Correspondence Study. Chicago: Center for the Study of Liberal Education for Adults. [26] Wikipedia (2012a). Distance education. Diunduh dari http://en.wikipedia.org/wiki/Distance_education 